\title{
Paraphyletic genus Ditylenchus Filipjev (Nematoda, Tylenchida), corresponding to the $D$. triformis-group and the D. dipsaci-group scheme
}

\author{
Yuejing Qiao', Qing Yu², Ahmed Badiss², Mohsin A. Zaidi², \\ Ekaterina Ponomareva², Yuegao $\mathrm{Hu}^{\prime}$, Weimin $\mathrm{Ye}^{3}$
}

I China Agriculture University, Beijing, China 2 Eastern Cereal and Oilseed Research Center, Agriculture and Agri-Food Canada, Ottawa, Ontario, Canada 3 Nematode Assay Section, Agronomic Division, North Carolina Department of Agriculture \& Consumer Services, NC, USA

Corresponding author: Qing Yu (Qing.Yu@agr.gc.ca)

Academic editor: H-P Fagerholm | Received 14 January 2015 | Accepted 1 February 2016 | Published 23 February 2016

http://zoobank.org/761198B0-1D54-43F3-AE81-A620DA0B9E81

Citation: Qiao Y, Yu Q, Badiss A, Zaidi MA, Ponomareva E, Hu Y, Ye W (2016) Paraphyletic genus Ditylenchus Filipjev (Nematoda, Tylenchida), corresponding to the D. triformis-group and the D. dipsaci-group scheme. ZooKeys 568: 1-12. doi: 10.3897/zookeys.568.5965

\begin{abstract}
The genus Ditylenchus has been divided into 2 groups: the $D$. triformis-group, and the $D$. dipsaci-group based on morphological and biological characters. A total of 18 populations belong to 5 species of Ditylenchus was studied: D. africanus, D. destructor, D. myceliophagus and dipsaci, D. weischeri, the first 3 belong to the $D$. triformis-group, the last 2 the $D$. dipsaci-group. The species of $D$. triformis-group were cultured on fungi, while the species from $D$. dispaci-group cultured on excised roots of plant hosts in petri dish. DNA sequences of regions of the nuclear ribosomal first internal transcribed spacer (ITS1) and the small subunit $18 \mathrm{~S}$ were PCR amplified, sequenced and the phylogenetic analyses also including the sequences of the closely related species from the GenBank. The randomly amplified polymorphisms of genomic DNA (RAPD) were also generated. Two clusters or clades corresponding to the 2 groups were consistently observed with significant statistical support from the 3 datasets. The phylogenetic analysis also revealed that the genus is paraphyletic, separating the 2 groups by species of Anguina and Subanguina.
\end{abstract}

Copyright Yuejing Qiao et al. This is an open access article distributed under the terms of the Creative Commons Attribution License (CC BY 4.0), which permits unrestricted use, distribution, and reproduction in any medium, provided the original author and source are credited. 


\section{Keywords}

Ditylenchus, ITS, 18 S ribosomal DNA, RAPD, genetic variations, mycophagous, plant parasitic nematodes, phylogeny

\section{Introduction}

The genus Ditylenchus Filipjev (1936) consists of 80-90 accepted species (Brzeski 1991) of either mycophagous, entomophlic or plant parasitic species. The genus includes some of the most destructive nematode pests, e.g. the mushroom spawn nematode $D$. myceliophagus Goodey 1958, the potato rot nematode D. destructor Thorne 1945, and the stem and bulb nematode D. dipsaci (Kühn, 1857) Filipjev 1936, the latter two are also internationally quarantined. As the climate change intensifies and international trade increases, invasive alien species such as nematode species are increasingly becoming serious problems, as demonstrated by the recent outbreak of the stem and bulb nematode in central Canada and the neighboring states of USA, (Yu et al. 2010, Qiao et al. 2013), and the recent finding of potato rot nematode in Ontario (Yu et al. 2012), which was the first finding on the continental Canada for the pest.

Taxonomy of the genus both above and below the rank has been confusing. The genus was first placed in the family Tylenchidae of Tylenchina (Filipjev 1936), moved to Anguillulina Schneider (1939) and moved again to Anguinidae (Paramonov 1970). The family has been moved between Hexatylina and Tylenchina (Siddiqi 1986, and 2000). Within the genus, species delimitation based on morphology has been rather arbitrary, since many morphometrical characters are highly variable and only a few were constant enough to be used for taxonomic purposes (Fortuner 1982). The species complex of D. dipsaci (Sturhan \& Brzeski, 1991) makes this situation even more confusing. Recently applications of molecular methods have provided new tools for researchers to better understand the biology and taxonomy of the genus. For example, $D$. weischeri Chizhov, Borisov \& Subbotin (2010) has been separated as a valid species from the $D$. dipsaci species complex, $D$. gigas Vovlas (2011) from the giant race of $D$. dipsaci, and D. africanus Wendt (1995) from $D$. destructor. Recent phylogenetic studies of ribosomal DNA indicated that the genus may be paraphyletic (Holterman et al. 2009; Giblin-Davis et al. 2010).

Two groups of the genus were recognized: the D. triformis-group and D. dipsacigroup (Siddiqi 1980). The D. triformis-group includes species with a rounded tail tip, lateral fields of six lines, and having mycophagous life cycle such as $D$. destructor and $D$. myceliophagous, while the $D$. dipsaci-group includes obligate plant parasites with a sharp-pointed tail tip and lateral fields of four lines. Those entomophlic species such as $D$. halictus are also mycophagous; belong to the D. triformis-group (Giblin-Davis et al. 2010).

The objective of the study was to use three molecular datasets, namely ITS1 and $18 \mathrm{~S}$ fragment sequences of ribosomal DNA and RAPD polymorphisms of genomic DNA, to determine the phylogenetic relationships of the two groups of Ditylenchus species. 


\section{Material and methods}

\section{Nematode population}

Live nematodes of eight populations of $D$. destructor, six populations of $D$. dipsaci, one of each $D$. africanus, $D$. weischeri and $D$. myceliophagus from different regions of three countries were collected (Table 1). Species identifications were confirmed using morphological and molecular methods.

\section{Nematode culturing}

Ditylenchus destructor, D. myceliophagus and D. africanus were cultured on Fusarium oxysporium on $10 \%$ potato dextrose agar (PDA). Ditylenchus dipsaci and D. weischeri were cultured on yellow pea and soybean excised roots on White's medium (White 1939) respectively but attempts were also made to culture $D$. dipsaic, and $D$. weischeri on F. oxysporium.

\section{Sample preparation}

PDA with fungus media and roots infested with nematodes were cut into small pieces and nematodes extracted using the Baermann funnel method (Baermann 1917).

\section{DNA extraction}

One or two extracted nematodes were subjected to DNA extraction. The nematodes were crushed in microtubes containing $40 \mu \mathrm{L} 10 \times \mathrm{PCR}$ buffer $(100 \mathrm{mM}$ Tris- $\mathrm{HCl}, \mathrm{pH}$ 9.0 at $\left.25^{\circ} \mathrm{C}, 500 \mathrm{mM} \mathrm{KCl}, 15 \mathrm{mM} \mathrm{MgCl}\right), 10 \mu \mathrm{L}$ Proteinase $\mathrm{K}(1 \mathrm{mg} / \mathrm{mL}), 50 \mu \mathrm{L}$ distilled water. The microtubes were incubated for $1.5 \mathrm{~h}$ at $65^{\circ} \mathrm{C}$ followed by $15 \mathrm{~min}$ at $95^{\circ} \mathrm{C}$ and stored at $-20^{\circ} \mathrm{C}$. DNA templates were quantified using a NanoDrop ND1000 Spectrophotometer (Wilmington, DE, USA).

\section{Sequencing and alignment of ITS1 and $18 S$ regions of nuclear rRNA}

A region of the internal transcribed spacer 1 (ITS1) gene was amplified using the primers ITS-F (5'-TTGATTACGTCCCTGCCCTTT-3'), ITS-R (5'-ACGAGCCGAGTGATCCACCG-3'). The amplification protocol was: initial denaturation at $94^{\circ} \mathrm{C}$ for $3 \mathrm{~min}$, followed by 40 cycles of denaturation $\left(30 \mathrm{~s}\right.$ at $\left.94^{\circ} \mathrm{C}\right)$, annealing $\left(45 \mathrm{~s}\right.$ at $58^{\circ} \mathrm{C}$ ), and extension $\left(2 \mathrm{~min}\right.$ at $72^{\circ} \mathrm{C}$ ), with a final extension for $10 \mathrm{~min}$ at $72{ }^{\circ} \mathrm{C}$. A region of the small subunit (SSU) $18 \mathrm{~S}$ rRNA gene (18S) was amplified 
Table I. Origins, hosts and access numbers of Ditylenchus species and populations used in this study

\begin{tabular}{|c|c|c|c|c|c|}
\hline \multirow{2}{*}{ Code } & \multirow{2}{*}{ Species } & \multirow{2}{*}{ Location } & \multirow{2}{*}{ Host } & \multicolumn{2}{|c|}{ Accession No. } \\
\hline & & & & ITS & $18 S$ \\
\hline CH01 & D. destructor & Inner Mongolia, China & Sweet potato & KJ567140 & KJ492926 \\
\hline CHO2 & D. destructor & Jilin, China & Sweet potato & KJ567141 & KJ492927 \\
\hline CH03 & D. destructor & Henan, China & Sweet potato & KJ567142 & KJ492928 \\
\hline CH04 & D. destructor & Shandong, China & Sweet potato & KJ567143 & KJ492929 \\
\hline CH05 & D. destructor & Jiangsu, China & Sweet potato & KJ567144 & KJ492930 \\
\hline CH06 & D. destructor & Hebei, China & Sweet potato & KJ567145 & KJ492931 \\
\hline CA01 & D. destructor & Ontario, Canada & Sweet potato & KJ567146 & KJ492932 \\
\hline CU01 & D. destructor & Clemson University, USA & Sweet potato & KJ567147 & KJ492933 \\
\hline CA02 & D. dipsaci & Ontario, Canada & Onion & KJ567148 & KJ492934 \\
\hline CU02 & D. dipsaci & Clemson University, USA & Garlic & KJ567149 & KJ492935 \\
\hline CA03 & D. dipsaci & Ontario, Canada & Garlic & KJ567150 & KJ492936 \\
\hline CA04 & D. dipsaci & Ontario, Canada & Garlic & KJ567151 & KJ492937 \\
\hline CA05 & D. dipsaci & Ontario, Canada & Garlic & KJ567152 & KJ492938 \\
\hline CA06 & D. dipsaci & Ontario, Canada & Garlic & KJ567153 & KJ492939 \\
\hline DA & D. africanus & South Africa & Peanut & KJ567154 & KJ492940 \\
\hline DW & D. weischeri & Manitoba, Canada & Canada thistle & KJ567155 & KJ492941 \\
\hline DM & D. myceliophagus & Ontario, Canada & Grass & KJ567156 & KJ492942 \\
\hline
\end{tabular}

using the primers $18 \mathrm{~S}-\mathrm{F}$ (5'-TTGGATAACTGTGGTTTAACTAG-3') and 18S-R (5'-ATTTCACCTCTCACGCAACA-3'). The amplification condition was: $95^{\circ} \mathrm{C}$ for $3 \mathrm{~min}$, followed by 40 cycles of $30 \mathrm{~s}$ at $95^{\circ} \mathrm{C}, 45 \mathrm{~s}$ at $60^{\circ} \mathrm{C}$ and $2 \mathrm{~min}$ at $72^{\circ} \mathrm{C}$, with final extension of $10 \mathrm{~min}$ at $72^{\circ} \mathrm{C}$. All PCR reactions were performed in $25 \mathrm{ul}$ volumes including $10 \mathrm{ng}$ DNA, $2.5 \mu \mathrm{l} 10 \times$ PCR buffer, $1.5 \mu \mathrm{l} 2.5 \mathrm{mM}$ dNTPs, $0.2 \mathrm{ul}$ $10 \mu \mathrm{M}$ primers and $0.25 \mu \mathrm{l}$ Titanium Taq DNA polymerase (supplier). The ITS and $18 \mathrm{~S}$ fragments were sequenced in-house with an ABI Prism 377 sequencer (Perkin Elmer) in both directions and unambiguous consensus sequences obtained. The sequences were deposited into the genBank database. DNA sequences were aligned by Clustal W (http://workbench.sdsc.edu, Bioinformatics and Computational Biology group, Dept. Bioengineering, UC San Diego, CA). The sequences were compared with those of the other nematode species available at the genBank sequence database using the BLAST homology search program. The model of base substitution was evaluated using MODELTEST (Posada and Crandall 1998; Huelsenbeck and Ronquist 2001). The Akaike-supported model, the base frequencies, the proportion of invariable sites and the gamma distribution shape parameters and substitution rates were used in phylogenetic analyses. Bayesian analysis was performed to confirm the tree topology for each gene separately using MrBayes 3.1.0 (Huelsenbeck and Ronquist 2001) running the chain for $1 \times 106$ generations and setting the "burnin" at 1,000. We used the Markov Chain Monte Carlo (MCMC) method within a Bayesian framework to estimate the posterior probabilities of the phylogenetic trees (Larget and Simon 1999) using 50\% majority rule. 


\section{RAPD (randomly amplified polymorphic DNA) and data analysis}

Twenty seven random primers were used for RAPD analysis. These primers were previously shown to be suitable for inter-species comparison of Ditylenchus (Digby and Kempton 1987; Zouhar et al. 2007). All PCR reactions were performed in $25 \mu \mathrm{l}$ volumes consisting of $1 \mu \mathrm{L}$ of genomic DNA prepared earlier as described above, $2.5 \mu \mathrm{l}$ of $10 \times$ PCR buffer, $1.25 \mu \mathrm{l}$ of $2.5 \mathrm{mM}$ dNTPs, and $0.25 \mu \mathrm{l}$ of Titanium Taq DNA polymerase (Clontech Lab Inc.). Amplification conditions were as follows: an initial denaturation at $94^{\circ} \mathrm{C}$ for $1 \mathrm{~min}$, followed by 40 cycles of denaturation at $94^{\circ} \mathrm{C}$ for $1 \mathrm{~min}$, annealing/extension at $72{ }^{\circ} \mathrm{C}$ for $1 \mathrm{~min}$ and a final extension at $72^{\circ} \mathrm{C}$ for $10 \mathrm{~min}$. The PCR products were separated by electrophoresis $(100 \mathrm{~V}, 1 \mathrm{~h})$ in $2.0 \%$ agarose gels in TAE buffer with 180-200 ng DNA. The gels were stained with ethidium bromide, visualized and photographed under UV-light (Bio-rad DX, USA). All reactions were repeated twice for clear and stable banding patterns. The presence or absence of DNA fragments was scored as one or zero, respectively, in the binary matrix. Simple matching coefficients (SM) (Digby and Kempton 1987) and hierarchical cluster analysis were performed with NTSYS2.1 (Exeter Software, Setauket, NY). Cluster analysis, by the un-weighted pair method with arithmetic mean (UPGMA), was performed with the SAHN (sequential, agglomerative, hierarchical and nested clustering method). The robustness of the dendrogram was tested with 1000 bootstrap replicates using PAUP software (Swofford 2003).

\section{Results}

DNA sequences: Ribosomal DNA fragments of the internal transcribed spacer 1 (404 bp) and fragments of the $18 \mathrm{~S}$ ribosomal RNA gene (902 bp) were amplified and sequenced and sequences deposited in GenBank (www.ncbi.nlm.nih.gov/genbank). GenBank accession numbers are listed in Table 1.

Phylogeny: Phylogenetic trees based on the ITS1 and $18 \mathrm{~S}$ sequences of rDNA are shown in Figures 1 and 2 respectively. The results are consistent for both ITS and $18 \mathrm{~S}$ with species separating into two clusters, one cluster comprising $D$. destructor, D. africanus and D. myceliophagus, and the second comprising D. dipsaci, D. weischeri and D. gigas, with the groupings corresponding well with the tail endings. The 2 clusters were separated by species of Anguina.

RAPD analysis: Among the 27 primers (excepting RAPD2, RAPD3, RAPD5, RAPD7, OPA17 and OPB16 which amplified no visible bands) 21 random primers produced clear and reproducible bands. A total of 212 bands ranging from 100-2000 bp in size were produced by the 21 primers. 121 and 42 polymorphic bands were obtained for $D$. destructor and $D$. dipsaci respectively, which suggests higher genetic variation among populations of the $D$. destructor than those of $D$. dipsaci. Figure 3 presents the RAPD profiles obtained from primers OPG-05 to exemplify the banding patterns observed. 


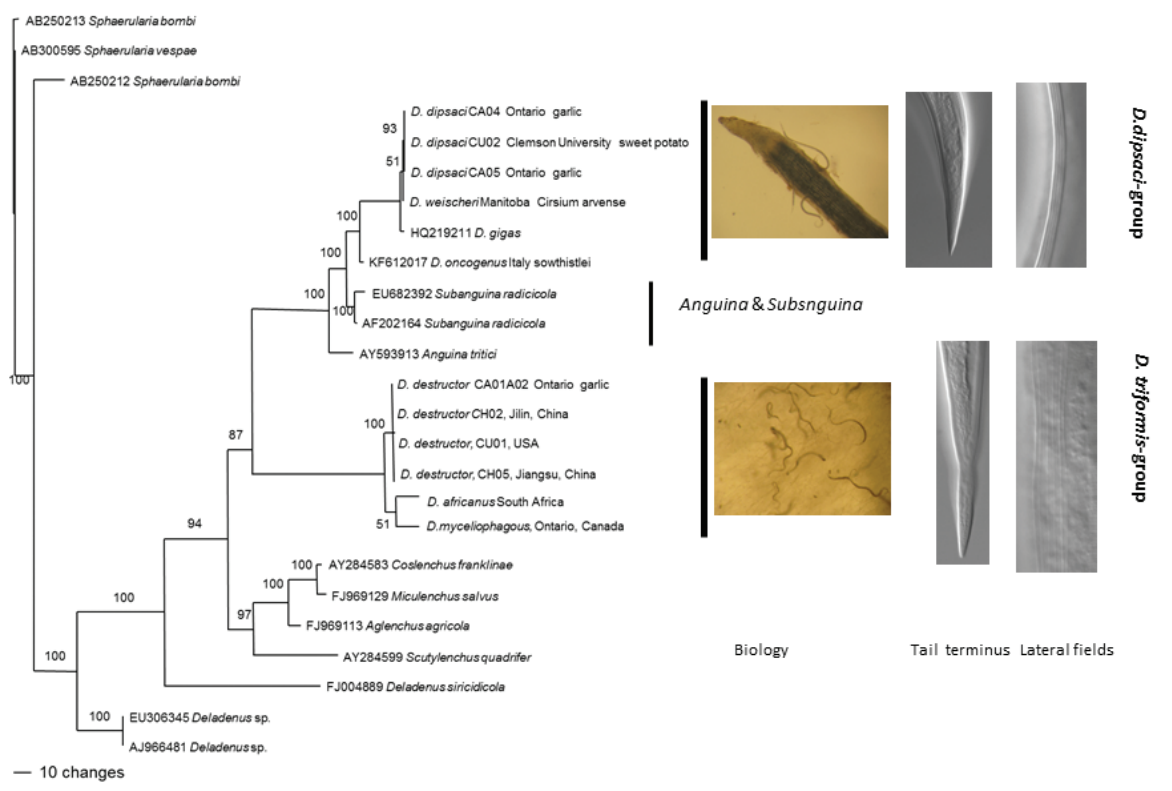

Figure I. The 10001st Bayesian likelihood tree inferred from ITS sequences under GTR+I+G model $(\operatorname{lnL}=9697.1895 ;$ freqA $=0.2646 ;$ freqC $=0.2062$; freq $=0.2602 ;$ freq $\mathrm{T}=0.269 ; \mathrm{R}(\mathrm{a})=0.9399$; $\mathrm{R}(\mathrm{b})=3.4936 ; \mathrm{R}(\mathrm{c})=2.4954 ; \mathrm{R}(\mathrm{d})=0.5528 ; \mathrm{R}(\mathrm{e})=5.2698 ; \mathrm{R}(\mathrm{f})=1$; Pinva = 0.4389; Shape = 0.7862). Posterior probability values exceeding $50 \%$ are given on appropriate clades.

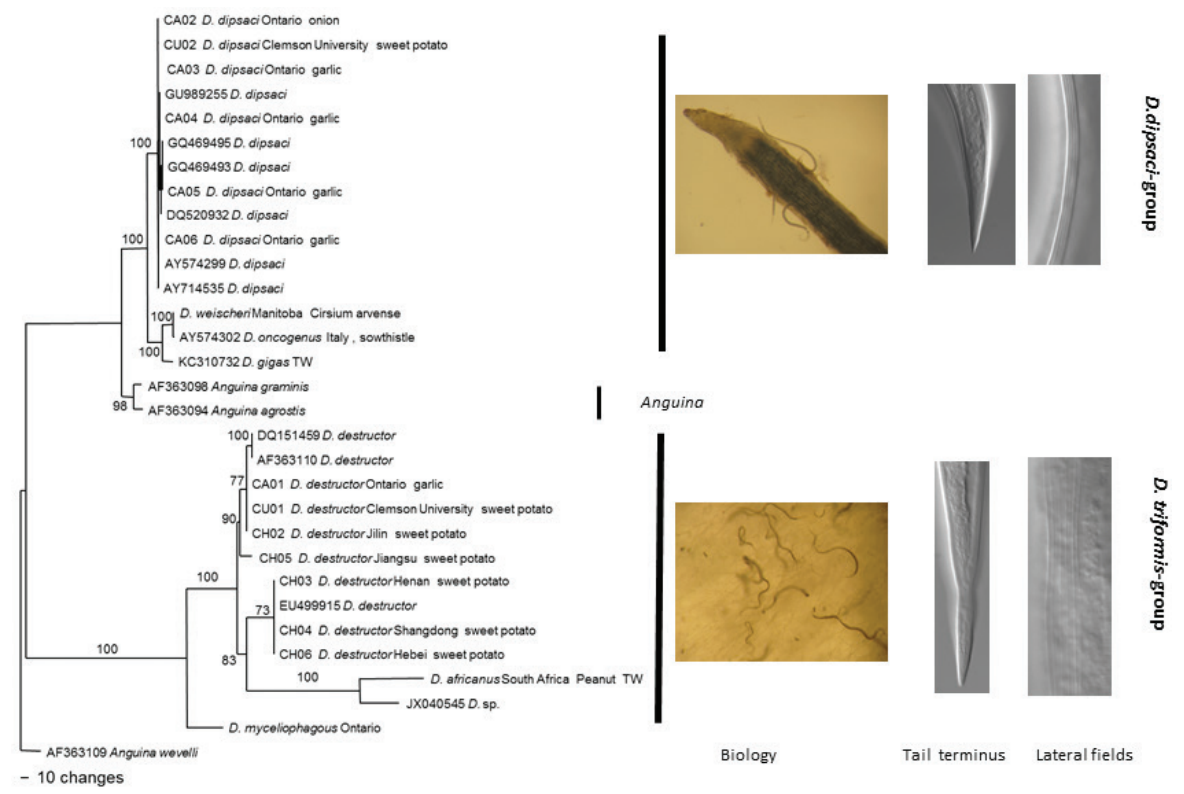

Figure 2. The 10001st Bayesian likelihood tree inferred from $18 \mathrm{~S}$ sequences under $\mathrm{GTR}+\mathrm{I}+\mathrm{G}$ model $(\operatorname{lnL}=9697.1895 ;$ freq $\mathrm{A}=0.2646 ;$ freq $\mathrm{C}=0.2062$; freq $=0.2602 ;$ freq $\mathrm{T}=0.269 ; \mathrm{R}(\mathrm{a})=0.9399$; $R(b)=3.4936 ; R(c)=2.4954 ; R(d)=0.5528 ; R(e)=5.2698 ; R(f)=1 ;$ Pinva = 0.4389; Shape = 0.7862). Posterior probability values exceeding $50 \%$ are given on appropriate clades. 


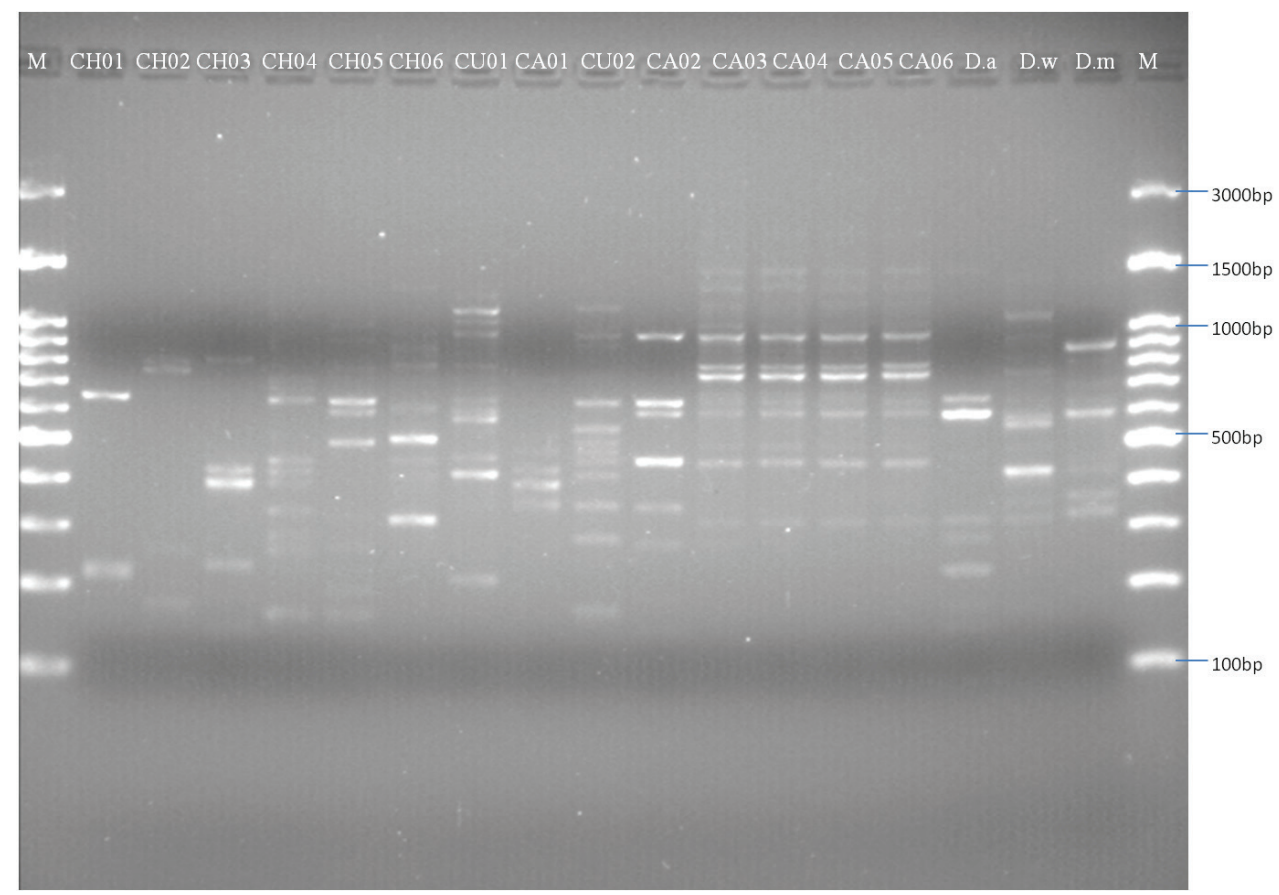

Figure 3. Random Amplified Polymorphic DNA (RAPD) profiles of all Ditylenchus species using primer OPG-05.

The RAPD binary data matrix and resulting simple matching coefficient (SM) are presented in Table 2. Figure 4 shows the dendrogram indicating the relationships among all collections. Species of Ditylenchus separated into two clusters consistent with the phylogenetic results based on the ITS1 and $18 \mathrm{~S}$ sequences. $D$. destructor, $D$. africanus, and $D$. myceliophagus comprised one cluster and D. dipsaci and D. weischeri the second cluster. All $D$. destructor populations were in one cluster with similarity of $74.2 \%$, and all six populations of $D$. dipsaci in the other cluster with a higher degree of genetic similarity (87\%).

\section{Conclusions}

All three molecular data supports morphological schemes for this genus to be divided into two groups: $D$. triformis-group and $D$. dipsaci-group, and that the genus is paraphyletic dividing along the group line by Anguina and Subanguina.

\section{Discussion}

The results of the study provide strong evidence for divide the genus into 2 groups, one for $D$. triformis-group and D. dipsaci-group, and genus is paraphyletic. Paraphyletic 


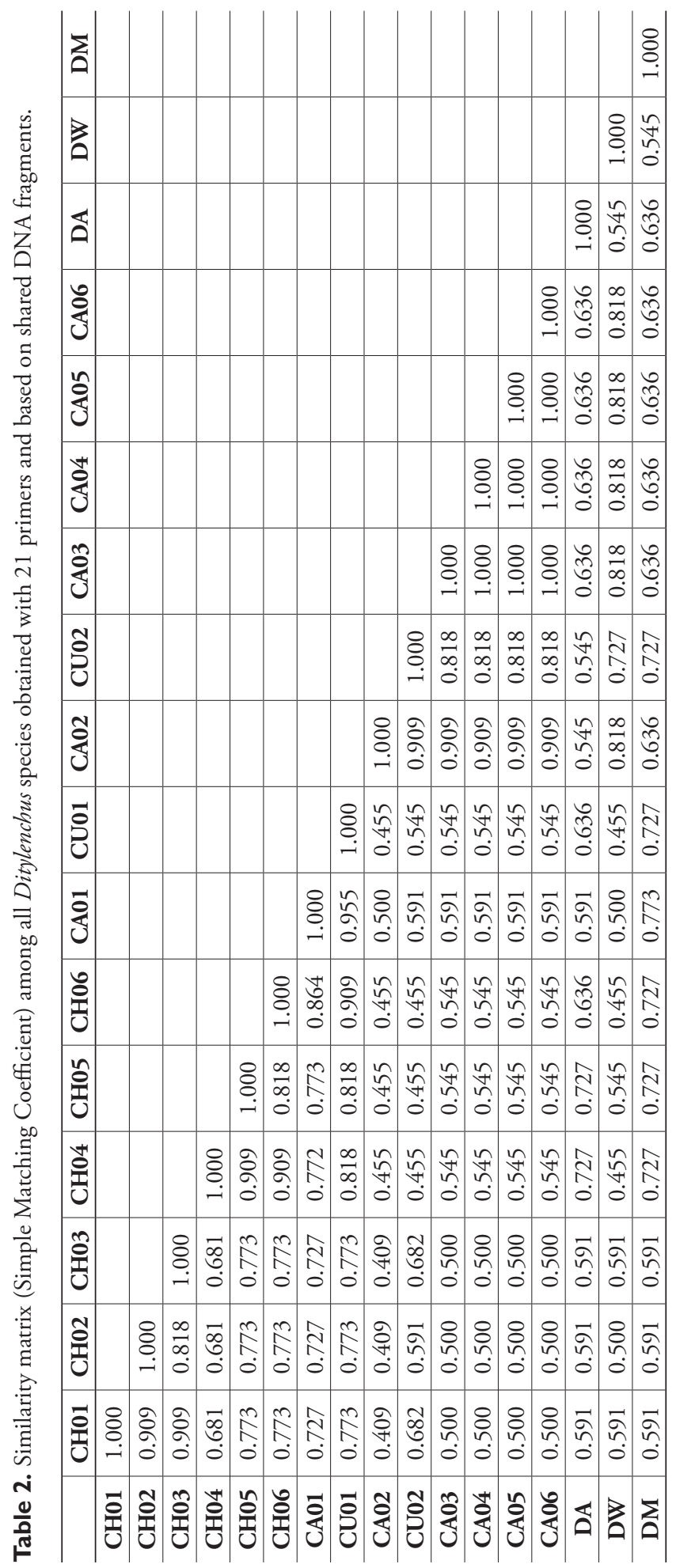



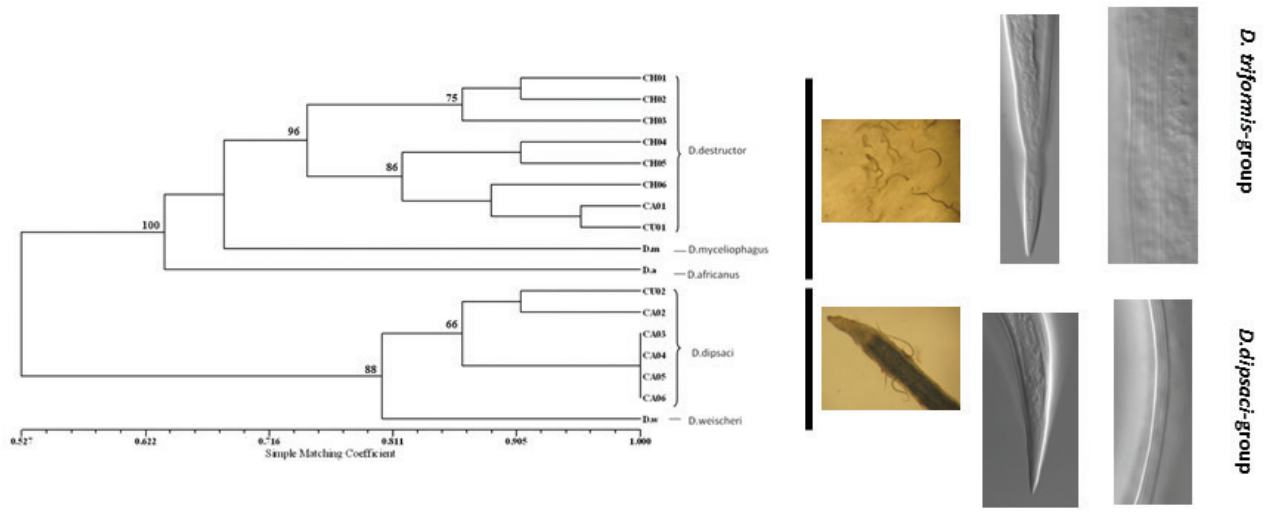

Biology Tail terminus Lateral fields

Figure 4. Un-weighted Pair Group Method with Arithmetic Mean (UPGMA) tree showing estimated average genetic distances among all Ditylenchus species based on simple matching coefficient obtained from RAPD analysis.

and polyphyletic taxa are nothing new to biosystematics, even in nematoda several taxa have been found either paraphyletic or polyphyletic: such as Hoplolaimus is paraphyletic (Bae et al. 2008, Ma et al. 2011) and Aphelenchoididae polyphyletic (Kanzaki et al. 2009). It is debateable whether non-monophyletic taxa should be accepted. However as taxonomy advances from traditional to phylogenetic; however, more and more researchers would reject paraphyletic or polyphyletic taxa since they are inconsistent with evolution.

When the genus Ditylenchus was established by Filipjev (1936) by synonymizing Tylenchus dipasci to D. dipsaci it was placed in the family Tylenchidae (Nematoda: Tylenchida) as the sister genus to Tylenchus. Even today differences between species of the two genera are primarily morphometric, although now the genus is placed in the family of Anguinidae. There is some molecular evidence suggesting that one of the evolutionary paths of plant parasitism in nematodes is from algae-feeding nematodes Tylenchus to Ditylenchus (Holterman et al. 2009), which may be true for the obligate plant parasitic Ditylenchus species since the sharp-pointed tail tip is a feature in common for the two genera. Morphologically, the D. triformis-group is closely related with Safianema, and there is also molecular evidence (Giblin-Davis 2010) that they belong to one clade, that the species of $D$. triformis-group should be synonymized into Safinema, and there are also molecular evidences that Safianema and D. triformis-group are closely related to Neotylenchidae (suborder Hexatylina) than to Tylenchidae (suborder: Tylenchina) (Robin-Davis 2010), and a rounded tail tip (shared characteristic for both D. triformis-group and Safianema) and is a shared character in Hexatylina. To resolve the synonymization and the eventual high rank placement of the putatively synonymized Safinema, more studies are needed. 


\section{Acknowledgements}

We thank the Chinese Scholarship Council for granting of a scholarship to the senior author to work in the laboratory of Dr. Qing Yu for this study. This study is one part of the doctoral thesis for the senior author. Thanks also go to Dr. Mario Tenuta, University of Manitoba for providing D. weischeri, Dr. Tom Prior, the Food and Environment Research Agency, UK for re-measuring the stylet length of D. myceliophagous, and to Dr. Sonia Steenkamp, ARC-Grain Crops Institute, South Africa for providing D. africanus. We also wish to thank Dr. John Bissett for reviewing the manuscript.

\section{References}

Bae CH, Szalanski AL, Robbins RT (2008) Molecular Analysis of the Lance Nematode, Hoplolaimus spp., Using the First Internal Transcribed Spacer and the D1-D3 Expansion Segments of 28S Ribosomal DNA. Journal of Nematology 40: 201-209.

Brzeski MW (1991) Review of the genus Ditylenchus Filipjev, 1936 (Nematoda : Anguinidae). Revue Nematology 14: 9-59.

Chizhov VN, Borisov BA, Subbotin SA (2010) A new stem nematode, Ditylenchus weischeri sp. n. (Nematoda: tylenchida), a parasite of Cirsium arvense (L.) Scop in the central region of the non-Chernozem zone of Russia. Russian Journal of Nematology 18: 95-102.

Digby P, Kempton RA (1987) Multivariate analysis of ecological communities. Chapman and Hall, London.

Filipjev IN (1936) On the classification of the Tylenchinae. Proceedings of the Helminthological Society of Washington 3: 80-82.

Fortuner R (1982) On the genus Dilylenchus Filipjev, 1936 (Nematoda: Tylenchida). Revue Nématologie 5: 17-38.

Giblin-Davis RM, Erteld C, Kanzaki N, Ye W, Zeng Y, Center B (2010) Ditylenchus halictus n. sp. (Nematoda: Anguinida), an associate of the sweat bee, Halicatus sexcinctus (Halictidae), from Germany. Nematology 12: 891-904. doi: 10.1163/138855410X494161

Goodey JB (1958) Ditylenchus myceliophagus n. sp. (Nematoda: Tylenchidae). Nematologica 3: 91-96. doi: 10.1163/187529258X00166

Huelsenbeck JP, Ronquist F (2001) MR BAYES: Bayesian inference of phylogenetic trees. Bioinformatics 17: 1754-755. doi: 10.1093/bioinformatics/17.8.754

Holterman M, Karssen G, Elsen VD, Ven Megen H, Bakker J, Helder J (2009) Small subunit rDNA phylogeny of the Tylenchida sheds light on relationships among some high-impact plant-parasitic nematodes and the evolution of plant feeding. Phytopathology 99: 227-235. doi: 10.1094/PHYTO-99-3-0227

Kanzaki N, Tanaka R, Giblin-Davis RM, Scheferahn RM, Center RH, Davies KA (2009) Pseudaphelenchus yukiae n.gen., n.sp. (Tylenchina: Aphelenchoididae) associated with Cylindrotermes marcrognathus (Termitidae: Termitinae) in La Selva, Costa Rica. Nematology 11: 869-881. doi: 10.1163/156854109X428034 
Larget B, Simon DL (1999) Markov chain Monte Carlo algorithms for the Bayesian analysis of phylogenetic trees. Molecular Biology and Evolution 16: 750-759. doi: 10.1093/oxfordjournals.molbev.a026160

Ma X, Agudelo P, Mueller JD, Knap HT (2011) Molecular Characterization and Phylogenetic Analysis of Hoplolaimus stephanus. Journal of Nematology 431: 25-34.

Paramonov AA (1970) Principles of phytohelminthology. Vol. III. Taxonomy of nematode superfamily Tylenchoidea. Nauka, Moskva, $253 \mathrm{pp}$.

Posada D, Crandall KA (1998) Modeltest: testing the model of DNA substitution. Bioinformatics 14: 817-818. doi: 10.1093/bioinformatics/14.9.817

Qiao Y, Zaidi M, Badiss A, Hughes B, Celetti MJ, Yu Q (2013) Intra-racial genetic variation of Ditylenchus dipsaci isolated from garlic in Ontario as revealed by random amplified polymorphic DNA analysis. Canadian Journal of Plant Pathology 35: 346-353. doi: $10.1080 / 07060661.2013 .804883$

Schneider W (1939) Wurmer order Vermes, II. Fadenwurmer order Nematoden. I. Freilebende und pflanzenparasitische Nematoden. Tierwelt Dutschlands (Dahl) 36: 1-260.

Siddiqi MR (1986) Tylenchida parasites of plants and insects. Commonwealth Agriculture Bureaux, Slough, U.K.

Siddiqi MR (2000) Tylenchida Parasites of Plants and Insects. 2nd ed. Commonwealth Agricultural Bureaux, London. doi: 10.1079/9780851992020.0000

Siddiqi MR (1980) Two new nematode genera, Safianema (Anguinidae) and Discotylenchus (Tylenchidae), with descriptions of three new species. Proceedings of the Helminthological Society of Washington 47: 85-94.

Sturhan D, Brzeski MW (1991) Stem and bulb nematodes, Ditylenchus spp. In: Nickle WR (Ed.) Manual of Agricultural Nematology. Marcel Dekker, New York, 423-464.

Swofford DL (2003) PAUP*. Phylogenetic Analysis Using Parsimony (* and Other Methods). Version 4. Sinauer Associates, Sunderland, Massachusetts.

Thorne G (1945) Ditylenchus destructor n. sp., the potato rot nematode, and Ditylenchus dipsaci (Kühn, 1857) Filipjev, 1936, the teasel nematode (Nematoda: Tylenchidae). Proceedings of the Helminthological Society of Washington 12: 27-34.

Vovlas N, Troccoli A, Palomares-rius JE, De Luca F, Liebanas G, Landa BB, Subbotin SA, Castillo P (2011) Ditylenchus gigas n. sp. parasitizing broad bean: a new stem nematode singled out from the Ditylenchus dipsaci species complex using a polyphasic approach with molecular phylogeny. Plant Pathology 60: 761-775. doi: 10.1111/j.13653059.2011.02430.x

Wendt KR, Swart A, Vrain TC, Webster JM (1995) Ditylenchus africanus sp. n. from South Africa: a morphological and molecular characterization. Fundamental and Applied Nematology 18: 241-250.

White PR (1939) Glycine in the nutrition of excised tomato roots. Plant Physiology 14: 527-538. doi: $10.1104 /$ pp.14.3.527

Yu Q, Ye W, Badiss A, Sun F (2010) Description of Ditylenchus dipsaci (Kühn, 1857) Filipjev, 1936 (Nematoda: Anguinidae) infesting garlic in Ontario, Canada. International journal of Nematology 20: 185-192. 
Yu Q, Zaidi MA, Hughes B, Celetti MJ (2012) Discovery of potato rot nematode, Ditylenchus destructor, infesting garlic in Ontario, Canada. Plant Diseases 96: 297. doi: 10.1094/PDIS08-11-0697

Zouhar M, Marek M, Douda O, Mazáková J, Rysanek P (2007) Conversion of sequencecharacterized amplified region (SCAR) bands into high-throughput DNA markers based on RAPD technique for detection of the stem nematode Ditylenchus dipsaci in crucial plant hosts. Plant Soil and Environment 53: 97-104. 